Prepared in cooperation with the Bureau of Reclamation

\title{
Using a Food Web Model to Inform the Design of River Restoration-An Example at the Barkley Bear Segment, Methow River, North-Central Washington
}

Open-File Report 2018-1002 



\section{Using a Food Web Model to Inform the Design of River Restoration-An Example at the Barkley Bear Segment, Methow River, North-Central Washington}

By Joseph R. Benjamin, J. Ryan Bellmore, and Daniel Dombroski

Prepared in cooperation with the Bureau of Reclamation

Open-File Report 2018-1002

U.S. Department of the Interior

U.S. Geological Survey 


\section{U.S. Department of the Interior \\ RYAN K. ZINKE, Secretary}

\section{U.S. Geological Survey \\ William H. Werkheiser, Deputy Director \\ exercising the authority of the Director}

U.S. Geological Survey, Reston, Virginia: 2018

For more information on the USGS-the Federal source for science about the Earth, its natural and living resources, natural hazards, and the environment-visit https://www.usgs.gov/ or call 1-888-ASK-USGS (1-888-275-8747).

For an overview of USGS information products, including maps, imagery, and publications, visit https:/store.usgs.gov.

Any use of trade, firm, or product names is for descriptive purposes only and does not imply endorsement by the U.S. Government.

Although this information product, for the most part, is in the public domain, it also may contain copyrighted materials as noted in the text. Permission to reproduce copyrighted items must be secured from the copyright owner.

Suggested citation:

Benjamin, J.R., Bellmore, J.R., and Dombroski, Daniel, 2018, Using a food web model to inform the design of river restoration-An example at the Barkley Bear Segment, Methow River, north-central Washington: U.S. Geological Survey Open-File Report 2018-1002, 24 p., https://doi.org/10.3133/ofr20181002.

ISSN 2331-1258 (online) 


\section{Contents}

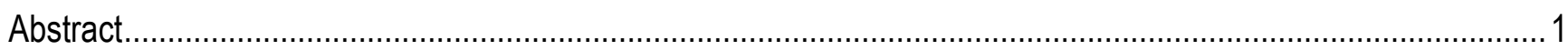





Study Area

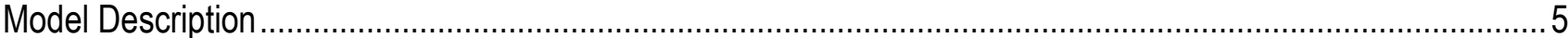

Restoration Design Process and Alternatives........................................................................................

Parameterizing and Running the ATP Model......................................................................................



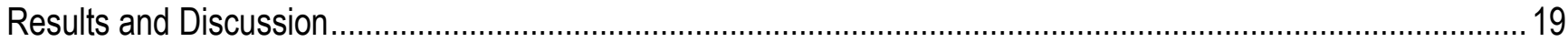





\section{Figures}

Figure 1. Images showing the Methow River watershed and the location of the Barkley Bear restoration segment and the location of the different river reaches within the site included in Aquatic Trophic Productivity model run), north-central Washington

Figure 2. Conceptual diagram of the Aquatic Trophic Productivity model showing biomass stocks of organisms and organic matter that make up the food web; consumer-resource interactions; inputs of energy, nutrients, and organic matter from outside the system; and explicit linkages to in-stream physical habitat and adjacent riparian vegetation

Figure 3. Images showing restoration alternative designs for the Barkley Bear segment, Methow River, north-central Washington

Figure 4. Graphical functions used in the Aquatic Trophic Productivity model that relate discharge in the main stem to the proportion of flow entering the side channel and Barkley canal, as well as discharge in the canal to the wetted length of the canal, for four restoration alternatives and background conditions, in the Barkley Bear segment, Methow River, north-central Washington

Figure 5. Graphical functions used in the Aquatic Trophic Productivity model that relate wetted channel width to discharge for the upstream treated main stem, downstream treated main stem, side channel, and Barkley canal, for four restoration alternatives and background conditions, in the Barkley Bear segment, Methow River, north-central Washington

Figure 6. Graphical functions used in the Aquatic Trophic Productivity model that relate average channel depth to discharge for the upstream treated main stem, downstream treated main stem, side channel, and Barkley canal, for four restoration alternatives and background conditions, in the Barkley Bear segment, Methow River, north-central Washington

Figure 7. Graphical functions used in the Aquatic Trophic Productivity model that relate the habitat suitability index to discharge for the upstream treated main stem, downstream treated main stem, side channel, and Barkley canal, for four restoration alternatives and background conditions, in the Barkley Bear segment, Methow River, north-central Washington

Figure 8. Graphs showing temporally dynamic environmental inputs used to parameterize the Aquatic Trophic Productivity model to the Barkley Bear restoration segment of the Methow River, north-central Washington

Figure 9. Graphs showing annual discharge and temperature used in model simulations, Methow River, north-central Washington

Figure 10. Graph showing percentage difference in the carrying capacity of juvenile Chinook salmon and steelhead in the Barkley Bear segment for each restoration design alternative based on Aquatic Trophic Productivity model simulations, Methow River, north-central Washington 
Figure 11. Graph showing percentage difference in the carrying capacity of juvenile Chinook salmon and steelhead for each river reach in the Barkley Bear segment under alternative restoration designs based on Aquatic Trophic Productivity model simulations, Methow River, north-central Washington ...

Figure 12. Graph showing percentage difference in the carrying capacity of juvenile Chinook salmon and steelhead in reach of the Barkley Bear segment for each restoration design alternative under different flow and temperature regimes, Methow River, north-central Washington

\section{Tables}

Table 1. Channel slope and length for each river restoration reach and restoration alternative of the Barkley Bear segment, Methow River, north-central Washington

Table 2. Values and sources of environmental input data used to parameterize the Aquatic Trophic Productivity model to the Barkley Bear restoration segment of the Methow River, north-central Washington

\section{Conversion Factors}

International System of Units to U.S. customary units

\begin{tabular}{|c|c|c|}
\hline Multiply & By & To obtain \\
\hline \multicolumn{3}{|c|}{ Length } \\
\hline meter $(\mathrm{m})$ & 3.281 & foot $(\mathrm{ft})$ \\
\hline kilometer $(\mathrm{km})$ & 0.6214 & mile (mi) \\
\hline \multicolumn{3}{|c|}{ Area } \\
\hline square meter $\left(\mathrm{m}^{2}\right)$ & 10.76 & square foot $\left(\mathrm{ft}^{2}\right)$ \\
\hline \multicolumn{3}{|c|}{ Volume } \\
\hline liter $(\mathrm{L})$ & 33.82 & ounce, fluid (fl. oz) \\
\hline \multicolumn{3}{|c|}{ Flow rate } \\
\hline cubic meter per second $\left(\mathrm{m}^{3} / \mathrm{s}\right)$ & 70.07 & acre-foot per day (acre-ft/d) \\
\hline cubic meter per second $\left(\mathrm{m}^{3} / \mathrm{s}\right)$ & 35.31 & cubic foot per second $\left(\mathrm{ft}^{3} / \mathrm{s}\right)$ \\
\hline \multicolumn{3}{|c|}{ Mass } \\
\hline milligram $(\mathrm{mg})$ & 0.00003527 & ounce, avoirdupois (oz) \\
\hline gram (g) & 0.03527 & ounce, avoirdupois (oz) \\
\hline
\end{tabular}

Temperature in degrees Celsius $\left({ }^{\circ} \mathrm{C}\right)$ may be converted to degrees Fahrenheit $\left({ }^{\circ} \mathrm{F}\right)$ as ${ }^{\circ} \mathrm{F}=\left(1.8 \times{ }^{\circ} \mathrm{C}\right)+32$.

\section{Supplemental Information}

Concentrations of chemical constituents in water are given in milligrams per liter (mg/L).

\section{Abbreviations}

$\begin{array}{ll}\text { AFDM } & \text { ash-free dry mass } \\ \text { ATP } & \text { Aquatic Trophic Productivity } \\ \text { DIN } & \text { dissolved inorganic nitrogen } \\ \text { HSI } & \text { habitat suitability index } \\ \text { NTU } & \text { Nephelometric Turbidity Unit } \\ \text { PAR } & \text { photosynthetically active radiation } \\ \text { rkm } & \text { river kilometer } \\ \text { SRP } & \text { soluble reactive phosphorus } \\ \text { USGS } & \text { U.S. Geological Survey }\end{array}$




\title{
Using a Food Web Model to Inform the Design of River Restoration-An Example at the Barkley Bear Segment, Methow River, North-Central Washington
}

By Joseph R. Benjamin ${ }^{1}$, J. Ryan Bellmore², and Daniel Dombroski

\begin{abstract}
With the decline of Chinook salmon (Oncorhynchus tshawytscha) and steelhead (O. mykiss), habitat restoration actions in freshwater tributaries have been implemented to improve conditions for juveniles. Typically, physical (for example, hydrologic and engineering) based models are used to design restoration alternatives with the assumption that biological responses will be improved with changes to the physical habitat. Biological models rarely are used. Here, we describe simulations of a food web model, the Aquatic Trophic Productivity (ATP) model, to aid in the design of a restoration project in the Methow River, north-central Washington. The ATP model mechanistically links environmental conditions of the stream to the dynamics of river food webs, and can be used to simulate how alternative river restoration designs influence the potential for river reaches to sustain fish production. Four restoration design alternatives were identified that encompassed varying levels of side channel and floodplain reconnection and large wood addition. Our model simulations suggest that design alternatives focused on reconnecting side channels and the adjacent floodplain may provide the greatest increase in fish capacity. These results were robust to a range of discharge and thermal regimes that naturally occur in the Methow River. Our results suggest that biological models, such as the ATP model, can be used during the restoration planning phase to increase the effectiveness of restoration actions. Moreover, the use of multiple modeling efforts, both physical and biological, when evaluating restoration design alternatives provides a better understanding of the potential outcome of restoration actions.
\end{abstract}

\footnotetext{
${ }^{1}$ U.S. Geological Survey.

${ }^{2}$ U.S. Forest Service.

${ }^{3}$ Bureau of Reclamation.
} 


\section{Introduction}

In the Columbia River Basin of the Northwestern U.S., Pacific salmon (Oncorhynchus spp.) and steelhead (O. mykiss) have declined to less than 10 percent of their historical population (Nehlsen and others, 1991). Links to the decline of salmon populations include, but are not limited, to landscape changes (for example, grazing, mining, logging, road construction, agriculture, and residential development), hydropower development, hatchery practices, and nonnative species (Independent Scientific Advisory Board, 2013). In an attempt to reverse the decline, multiple restoration actions have occurred in freshwater tributaries. Many of these restoration actions focus on modifying channel structure (for example, large wood additions, side channel reconnection) to increase and (or) improve habitat for fish.

Traditional approaches for designing restoration alternatives have relied heavily on outputs of hydraulic and other geomorphic-based models (Harris and Heathwaite, 2011), with the assumption that changes in physical habitat will benefit population level dynamics such as reproduction, juvenile survival, or migratory cues of the target fish (Wipfli and Baxter, 2010). However, the effect of river restoration on salmon and steelhead populations has been inconsistent (Independent Scientific Advisory Board, 2013). This may not be surprising given that most restoration practices not only affect these target fish, but also all the other organisms that interact with these fish, including competitors, predators and prey. Juvenile salmon and steelhead can be strongly influenced by food web interactions, such as food availability (for example, Richardson, 1993; Kiffney and others, 2014), competition for shared food resources (for example, Bellmore and others 2013), and predation by organisms that occupy higher trophic positions (for example, Fresh, 1997; Yard and others, 2011). Explicit treatment of biological processes in the models that inform restoration design is needed (Palmer and others, 2005; Naiman and others, 2012; Roni and Beechie, 2013), and may improve the chances of reaching desired outcomes of restoration projects.

We developed a food-web model that can be used to evaluate a suite of management applications, including habitat restoration (Benjamin and Bellmore, 2016; Bellmore and others, 2017). Our food web model, called the Aquatic Trophic Productivity (ATP) model, mechanistically links environmental conditions of the stream and adjacent riparian zone to the dynamics of river food webs. The model can be used to simulate how changes to environmental conditions associated with alternative river restoration designs influence the potential for river reaches to sustain fish production through changes to the food web within which these organisms participate. This model previously has been used to evaluate food web and fish responses to a variety of different restoration treatments in the Methow River in north-central Washington (Benjamin and Bellmore, 2016; Bellmore and others, 2017). These previous analyses illustrated that ATP model simulations are realistic and closely match the value of available empirical data (Bellmore and others, 2017). 
The purpose of this report is to describe simulations from the ATP model that helped inform the initial stages of restoration design in a $1-\mathrm{km}$ reach (termed the Barkley Bear segment) of the Methow River (Bureau of Reclamation, 2016). The target of this restoration action-and most other river restoration actions in the Methow River watershed-is the recovery of ESA-listed spring Chinook salmon (O. tshawytscha) and steelhead. Although the ATP model has been applied previously in the Methow River to examine potential fish responses to restoration, this was the first opportunity for the ATP model to be used during the restoration design process. All design alternatives were focused on changing the physical habitat by reconnecting the main stem to floodplain habitat (that is, reconnecting or creating new side channels) and building complexity (that is, large wood aggregates). Additional models used to help inform the restoration design included a two-dimensional hydraulic model (Lai, 2010) and a spatially explicit habitat suitability index (HSI) model (Dombroski and others, 2012). The Methow Salmon Recovery Foundation, Upper Columbia Salmon Recovery Board, Bureau of Reclamation, Bonneville Power Administration, Anchor QEA, and the U.S. Geological Survey (USGS) collaborated to develop and evaluate restoration design alternatives.

\section{Methods}

\section{Study Area}

The Methow River, located in north-central Washington, originates in the North Cascade Mountains and drains southeast to the confluence with the Columbia River (fig. 1). Precipitation primarily is in the form of snowfall, with peak flows occurring in May and June and base flows persisting from July through October. Mean annual discharge of the Methow River was $34.3 \pm 2.0 \mathrm{~m}^{3} / \mathrm{s}$ ( \pm standard error; downloaded at http://waterdata.usgs.gov, site No. 12448500, Methow River at Winthrop, Washington, from 1990 to 2015). Primary fish species present in the main-stem Methow River include Endangered Species Act (16 U.S.C. § 1531 et seq.)-listed Upper Columbia summer steelhead and rainbow trout, Upper Columbia spring Chinook salmon, summer Chinook salmon, coho salmon (O. kisutch), Pacific lamprey (Entosphenus tridentatus), mountain whitefish (Prosopium williamsoni), westslope cutthroat trout (O. clarkii lewisi), bull trout (Salvelinus confluentus), brook trout (S. fontinalis), longnose dace (Rhinichthys cataractae), bridgelip sucker (Catostomus columbianus), and several sculpin species (Cottus spp.).

The Barkley Bear segment is located at rkm 50 of the Methow River, which is a relatively unconfined river-floodplain segment (fig. 1). Much of the surface of the floodplain in the middle section of the Methow River, including the Barkley Bear segment, has been developed for agricultural and residential use, resulting in deforestation and disconnection of the river from adjacent floodplain habitat because of diking (Bureau of Reclamation, 2010). The Barkley Bear segment is surrounded by private land on both river banks, and includes (1) a short side channel, (2) the confluence with Bear Creek, and (3) the diversion inlet to Barkley Canal (hereinafter "canal"). Bear Creek is a highly channelized, first-order stream with minimal flow $\left(<0.05 \mathrm{~m}^{3} / \mathrm{s}\right.$ base flow) owing to upstream water diversions, which are outside the restoration project area. The canal diverts about $0.3-0.6 \mathrm{~m}^{3} / \mathrm{s}$ from the main-stem Methow River between May and October for agricultural irrigation (Ely, 2003). To maintain the Barkley canal, a seasonal push-up dam was constructed by bulldozing sediment from the canal to the main stem, upstream of the inlet. In 2013, the building of the push-up dam was stopped because this level of disturbance raised concern for listed fish species, as well as other aquatic organisms. Moreover, juvenile Chinook salmon and steelhead used the canal as rearing habitat and often suffered increased mortality from stranding during dewatering. In 2016, a process began to abandon the canal intake. With landowner cooperation, the river reach was identified as a high priority site for restoration to improve rearing habitat for spring Chinook salmon and steelhead. 




Upstream main stem

Upstream treated main stem

Side channel

Downstream treated main stem

Barkley canal

Bear Creek

Figure 1. Images showing the Methow River watershed and the location of the Barkley Bear restoration segment (black oval; A) and the location of the different river reaches within the site included in Aquatic Trophic Productivity model runs (B), north-central Washington. Image source: Google Earth ${ }^{\mathrm{TM}}$. 


\section{Model Description}

The ATP model has been described in detail, including a comprehensive list of parameters, sensitivity analyses, and coding (Benjamin and Bellmore, 2016; Bellmore and others, 2017). A general overview with points pertinent to the evaluation of the initial Barkley Bear restoration design alternatives is provided herein.

The ATP model is a dynamic food-web simulation tool, whereby the capacity of stream and river ecosystems to sustain fish is linked explicitly to transfers of organic matter between different components of a simplified river food web (fig. 2). The model mechanistically links the dynamics of the food-web and the resultant performance of different web members to (1) the physical and hydraulic conditions of the stream, and (2) the structure and composition of the adjacent riparian zone. The modeling framework assumes that the general dynamics of river food webs can be predicted if the dynamics of these two environmental factors are known (Power and Dietrich, 2002). Following this assumption, the model can be used to examine how environmental changes resulting from restoration might affect the overall dynamics of the food web and the performance of specific web members.

The food web component of the model contains four biomass stocks or state variables:

1. Periphyton,

2. Terrestrially derived organic matter (that is, leaf litter),

3. Aquatic invertebrates, and

4. Fish (fig. 2).

In the model, periphyton and terrestrial detritus are consumed by aquatic invertebrates, and aquatic invertebrates are consumed by fish (target and non-target stocks). The fish stock includes a "target" fish stock that represents juvenile Chinook salmon and steelhead, and a "non-target" fish stock that represents the rest of the fish in the community (for example, whitefish, sculpin, bull trout, cutthroat trout, rainbow trout, and longnose dace). Based on previous research, we assumed that the non-target fish stock both competes with and preys upon the target fish stock (Bellmore and others, 2013; Benjamin and others, 2014; Martens and Connolly, 2014). However, we assumed that large predatory fish would not be present in the side channel or canal (see fig. 1), and that the canal would serve as a refuge from competition for the target fish stock (that is, non-target fish were not present). The dynamics of each stock are governed by a series of mass balance equations (see Bellmore and others, 2017). Biomass increases if the processes that contribute to biomass gains (for example, consumption and energy assimilation, upstream/lateral inputs, and production) outweigh the processes that contribute to biomass losses (for example, predation, downstream export, and respiration). Energy and materials that enter the modeled reach from external locations include:

1. Light, which provides the energy for photosynthesis;

2. Nutrients and organic material from upstream reaches, which provide resources necessary for periphyton production; and

3. Lateral inputs from the riparian zone, which provide detrital organic matter (leaf litter) and direct food resources (terrestrial invertebrates) for fish. 




Figure 2. Conceptual diagram of the Aquatic Trophic Productivity model showing biomass stocks of organisms and organic matter (rectangular boxes) that make up the food web; consumer-resource interactions (thick, curved arrows); inputs of energy, nutrients, and organic matter from outside the system (thin arrows); and explicit linkages to in-stream physical habitat and adjacent riparian vegetation. Figure modified from Bellmore and others (2017).

The environmental conditions of the reach drive the dynamics represented in the food web. For example, temperature strongly affects the bioenergetics of organisms (that is, consumption and respiration rates) and decay rates of organic matter. Channel discharge and hydraulics directly influence channel width, water depth, velocity, and shear stress, which in turn, influence the amount of light reaching the streambed to fuel photosynthesis, the amount of wetted area available for biological productivity to occur, the capacity of the river reach to retain organic matter and organisms, and the amount of habitat that is suitable for fish (HSI; Raleigh and others, 1986). Incoming light and shading determine how much photosynthetically active radiation is available to fuel periphyton production. Water turbidity, in conjunction with water depth, determines how much of this light is attenuated before it reaches the streambed. The amount and cover of riparian vegetation influences the flux of terrestrial leaf litter and invertebrates to the stream, and the proportion of the stream that is shaded. 


\section{Restoration Design Process and Alternatives}

The refinement of restoration alternatives was an iterative process, involving frequent meetings of stakeholders over the course of design initiation and revision. Stakeholders (also known as the design team) who participated included individuals representing the Methow Salmon Recovery Foundation, Upper Columbia Salmon Recovery Board, Bureau of Reclamation, Bonneville Power Administration, Anchor QEA, and USGS. Stakeholders identified the designs to evaluate based on identified logistics and constraints that were set with public input. For example, access to private land and the willingness of the landowner to allow restoration to occur needed to be considered, as well as safe passage through the river for boaters. Our approach to address the needs of the restoration design alternatives was more within the framework of decision support (Gregory and others, 2012) than one of active participation in the design process.

The fundamental objective of the design alternatives was to decommission the canal infrastructure in a way that increases and improves habitat available for various life stages of juvenile Chinook salmon and steelhead. Means to achieve this objective included reconnecting or constructing side channels, reactivating floodplain dynamics, and increasing channel complexity (for example, hydraulic structures such as large wood complexes). Four design alternatives were selected by the stakeholders (fig. 3). The designs encompassed significant variation in the level of channel manipulation. Alternatives for reconnecting Bear Creek were included in the restoration designs, but were not evaluated with the ATP model because empirical and hydraulic modeling data were not available to uniquely parameterize each alternative. Regardless of this, Bear Creek has relatively little flow, and its confluence with the main stem was designed to occur near the bottom of the downstream treated main-stem reach, which would likely have little influence on the outcome of the ATP model results. We identify components of the restoration alternatives that are applicable to the ATP model simulations and results as follows, albeit some components of each alternative were not evaluated with the ATP model and not included in the description:

Alternative 1. Design alternative 1 was focused on the removal of anthropogenic structures that might compromise geomorphic processes. Key elements for this alternative included decommissioning the canal by filling and removing its infrastructure, redistributing large wood that was removed from the canal to the existing side channel and floodplain, and removing a levee and riprap in the downstream reach to reconnect the floodplain. The rationale for filling the canal was to prevent the stranding of juvenile fish, including Chinook salmon and steelhead, when water flow was stopped by closing the head gates.

Alternative 2. Design alternative 2 was focused on geomorphic processes that may provide long-term benefit to fish. Key elements of this alternative included those identified in alternative 1, with the exception of connecting the upper part of the canal to act as an additional side channel. In this alternative, a proportion of the flow from the main stem would enter the canal, and the canal would be connected directly to the main channel in the middle of the restoration reach. This would reduce the length of the canal to about one-half of the background conditions. The channel morphology and associated hydraulics of the canal would remain similar to background conditions; however, the head gate would be removed to allow perennial connectivity. Additionally, large engineered log jams would be placed in the upstream end of the side channel and the downstream treated reach, with the dual goals of directing flow and providing habitat for fish. 

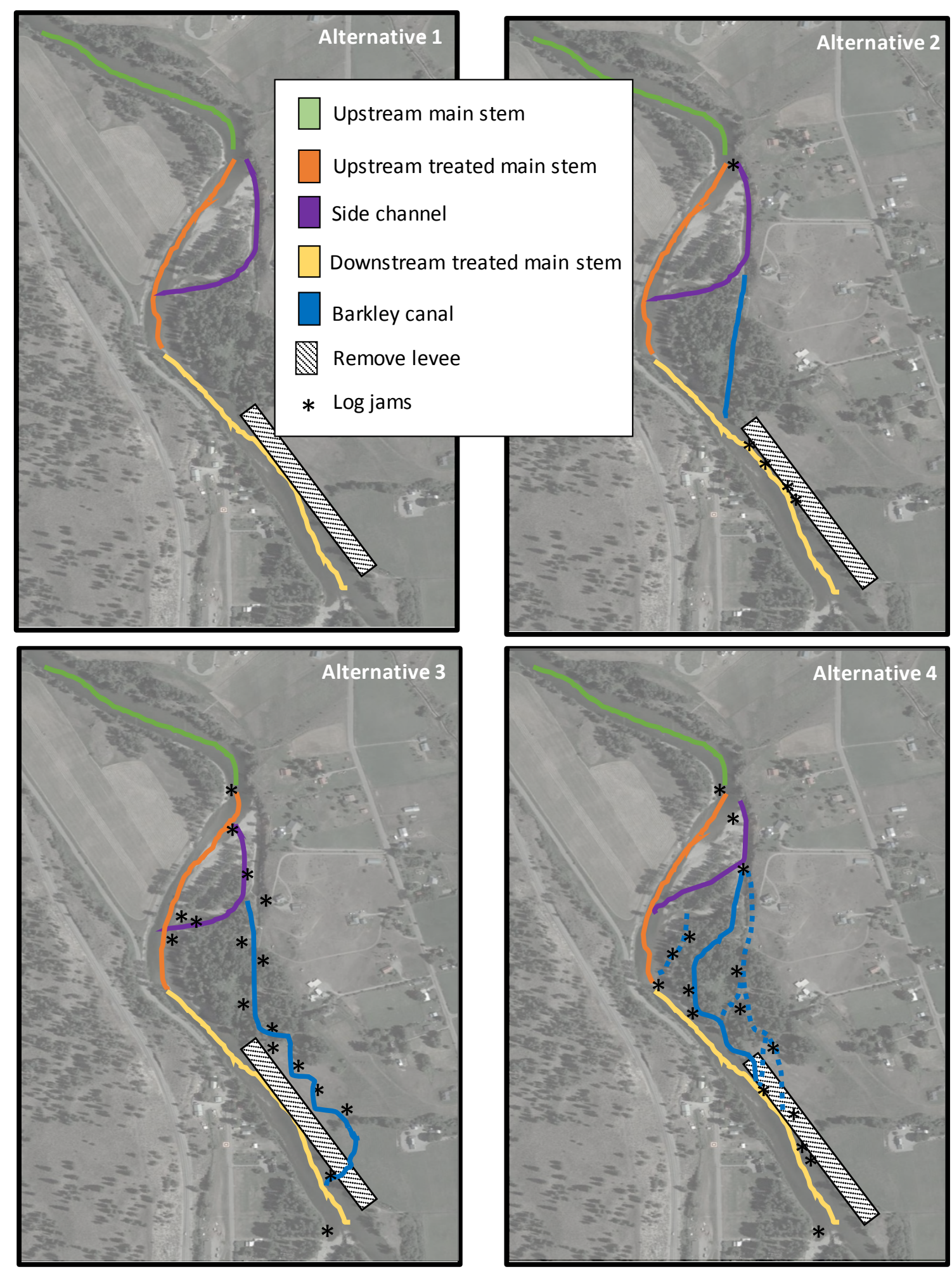

Figure 3. Images showing restoration alternative designs for the Barkley Bear segment, Methow River, northcentral Washington. Dashed lines in alternative 4 denote ephemeral channels. Image source: Google Earth ${ }^{\mathrm{TM}}$. 
Alternative 3. Design alternative 3 was focused on maximizing fish habitat through floodplain reconnection. In addition to most of the elements identified in alternative 2 , this alternative approximately doubled the proportion of flow entering the side channel and canal. This would result in increased inundation and floodplain connectivity. Additional log jams were designed in the side channel to increase habitat and divert flow.

Alternative 4. Similar to alternative 3, the design focus of alternative 4 was to maximize fish habitat and promote floodplain evolution. Key elements of this alternative were similar to those of alternative 3 , except that, instead of one long side channel developed from the canal, a network of side channels was designed through the canal reach. Additionally, more log jams were included to alter flow and promote creation of the side-channel network.

\section{Parameterizing and Running the ATP Model}

The environmental parameters that changed with the restoration alternatives that were modified within the ATP model included the following:

- The proportion of flow entering the side channel and canal;

- The wetted length of the canal (fig. 4);

- Changes in width, depth, and HSI for fish as a function of discharge (figs. 5-7); and

- Channel slope (table 1).

For HSI, we used curves created for juvenile Chinook salmon (Raleigh and others, 1986). We summarized information from two-dimensional hydraulic models (Bureau of Reclamation, 2010, 2012) to create graphical functions of the relationship of discharge to wetted width, average water depth and HSI within each reach of the Barkley Bear segment (see Benjamin and Bellmore, 2016; Bellmore and others, 2017 for more information).

We assumed that the temporally dynamic values of most environmental inputs used in the ATP model were identical among reaches (for example, water temperature, nutrient concentrations, and turbidity; fig. 8; table 2). Values used were collected from the Methow River within or in close proximity to the Barkley Bear segment during previous monitoring and modeling efforts (Benjamin and Bellmore, 2016). However, Surveys for three parameters were collected specifically for the Barkley Bear restoration design simulations. First, riparian vegetation coverage was estimated by analyzing aerial site photographs. The amount and composition of riparian vegetation was converted into estimates of leaf litter inputs using published relationships between tree diameter and foliage biomass (Jenkins and others, 2004). Second, stream shading was calculated from Solar-Pathfinder ${ }^{\mathrm{TM}}$ surveys. Third, substrate distributions were estimated from a Wolman pebble count. 
Model results were focused on the difference in carrying capacity of juvenile Chinook salmon and steelhead, which were the target fish of the Barkley Bear restoration project. Specifically, we used modeled outputs to calculate the relative difference in fish biomass between background conditions (or no restoration action) and each restoration alternative. Additionally, we can make comparisons at the scale of individual reaches (that is, upstream or downstream treated main stem, side channel, canal; figs. 1, 3), which allows the relative contributions of each reach to be evaluated. Estimates of carrying capacity were in grams of ash-free dry mass (AFDM) per meter of stream length. All simulations ran for 3,650 days (10 years), starting on 1 January. Results are reported for the final 365 days of the model simulation, after the model had equilibrated to initial conditions, which took about 1,095 days (3 years). STELLA ${ }^{\circledR} 10.1$ (ISEE Systems, Lebanon, New Hampshire) was used to construct the model and run the simulations.

Table 1. Channel slope and length for each river restoration reach and restoration alternative of the Barkley Bear segment, Methow River, north-central Washington.

[Slope and length for background conditions are the same as those used for each alternative. Slope and length of the canal are not applicable (NA) for Alternative 1. Metric: Slope in meter per meter, Length in meters]

\begin{tabular}{cccccc}
\hline Alternative & Metric & $\begin{array}{c}\text { Upstream treated } \\
\text { main stem }\end{array}$ & $\begin{array}{c}\text { Downstream treated } \\
\text { main stem }\end{array}$ & $\begin{array}{c}\text { Side } \\
\text { channel }\end{array}$ & Canal \\
\hline 1 & Slope & 0.0015 & 0.0015 & 0.003 & NA \\
2 & Slope & 0.0015 & 0.0015 & 0.003 & 0.003 \\
3 & Slope & 0.004 & 0.0015 & 0.003 & 0.0006 \\
4 & Slope & 0.003 & 0.0015 & 0.0016 & 0.0014 \\
1 & Length & 343 & 652 & 327 & NA \\
2 & Length & 343 & 652 & 327 & See figure 4C \\
3 & Length & 343 & 652 & 327 & See figure 4C. \\
4 & Length & 343 & 652 & 327 & See figure 4C. \\
\hline
\end{tabular}


Table 2. Values and sources of environmental input data used to parameterize the Aquatic Trophic Productivity model to the Barkley Bear restoration segment of the Methow River, north-central Washington.

$\left[{ }^{\circ} \mathrm{C}\right.$, degrees Celsius; g AFDM $/ \mathrm{m}^{2}$, grams ash-free dry mass per square meter; $\mathrm{m}$, meter; $\mathrm{mg} / \mathrm{L}$, milligram per liter; $\left[\left(\mathrm{mol} / \mathrm{m}^{2}\right) / \mathrm{d}\right]$, mole per square meter per day; $\mathrm{m}^{3} / \mathrm{s}$, cubic meter per second $]$

\begin{tabular}{|c|c|c|c|c|}
\hline $\begin{array}{l}\text { Environmental } \\
\text { input }\end{array}$ & Units & $\begin{array}{l}\text { Variable } \\
\text { type }\end{array}$ & Used values & Source \\
\hline Discharge & $\mathrm{m}^{3} / \mathrm{s}$ & $\begin{array}{c}\text { Temporally } \\
\text { dynamic }\end{array}$ & See figures 8 and 9. & $\begin{array}{l}\text { National Water Information System, U.S. } \\
\text { Geological Survey streamgage } 12448500 \\
\text { (Methow River at Winthrop, Washington); } \\
\text { daily average from } 1912 \text { to } 2012 \\
\text { (http://waterdata.usgs.gov/nwis, accessed } \\
\text { February 2013). }\end{array}$ \\
\hline Water temperature & ${ }^{\circ} \mathrm{C}$ & $\begin{array}{l}\text { Temporally } \\
\text { dynamic }\end{array}$ & See figures 8 and 9. & Benjamin and Bellmore, 2016. \\
\hline $\begin{array}{l}\text { Nephelometric } \\
\text { turbidity }\end{array}$ & NTU & $\begin{array}{l}\text { Temporally } \\
\text { dynamic }\end{array}$ & See figure 8 . & $\begin{array}{l}\text { Washington Department of Ecology water } \\
\text { quality monitoring station 48A140 } \\
\text { (Methow River at Twisp); monthly } \\
\text { average 1995-2012 } \\
\text { (https://fortress.wa.gov/ecy/eap/riverwq, } \\
\text { accessed February 2013). }\end{array}$ \\
\hline $\begin{array}{l}\text { Dissolved } \\
\text { inorganic } \\
\text { nitrogen (DIN) }\end{array}$ & $\mathrm{mg} / \mathrm{L}$ & $\begin{array}{l}\text { Temporally } \\
\text { dynamic }\end{array}$ & See figure 8 . & Same source as turbidity. \\
\hline $\begin{array}{l}\text { Soluble reactive } \\
\text { phosphorus } \\
\text { (SRP) }\end{array}$ & $\mathrm{mg} / \mathrm{L}$ & $\begin{array}{l}\text { Temporally } \\
\text { dynamic }\end{array}$ & See figure 8 . & Same source as turbidity. \\
\hline Leaf litter input & $\mathrm{g} \mathrm{AFDM} / \mathrm{m}^{2}$ & $\begin{array}{l}\text { Temporally } \\
\text { dynamic }\end{array}$ & See figure 8 . & Estimated from aerial photographs. \\
\hline Shading & - & $\begin{array}{l}\text { Temporally } \\
\text { dynamic }\end{array}$ & See figure 8 . & Collected at site using Solar-Pathfinder ${ }^{\mathrm{TM}}$. \\
\hline $\begin{array}{l}\text { Photosynthetically } \\
\text { active radiation } \\
\text { (PAR) }\end{array}$ & {$\left[\left(\mathrm{mol} / \mathrm{m}^{2}\right) / \mathrm{d}\right]$} & $\begin{array}{l}\text { Temporally } \\
\text { dynamic }\end{array}$ & See figure 8 . & $\begin{array}{l}\text { U.S. Department of Agriculture, UV-B } \\
\text { Monitoring and Research Program, } \\
\text { Pullman, Washington; daily average } \\
\text { 2004-12 } \\
\text { (http://uvb.nrel.colostate.edu/UVB, } \\
\text { accessed February 2013). }\end{array}$ \\
\hline $\begin{array}{l}\text { Proportion of } \\
\text { stream covered } \\
\text { by vegetation }\end{array}$ & - & Constant & 0.1 & Estimated from aerial photographs. \\
\hline $\begin{array}{r}\text { Substrate size } \\
\text { distribution }\end{array}$ & $\mathrm{m}$ & $\begin{array}{l}\text { Cumulative } \\
\text { Distribution }\end{array}$ & ${ }^{1} 0.11$ & $\begin{array}{l}\text { Collected at site using Wolman pebble } \\
\text { counts. }\end{array}$ \\
\hline
\end{tabular}

${ }^{1}$ Median substrate size (D50) of distribution. 



Figure 4. Graphical functions used in the Aquatic Trophic Productivity model that relate discharge (in cubic meters per second $\left.\left[\mathrm{m}^{3} / \mathrm{s}\right]\right)$ in the main stem to the proportion of flow entering the side channel $(\mathrm{A})$ and Barkley canal (B), as well as discharge in the canal to the wetted length of the canal (in meters [m]; C), for four restoration alternatives and background conditions, in the Barkley Bear segment, Methow River, north-central Washington. 



Figure 5. Graphical functions used in the Aquatic Trophic Productivity model that relate wetted channel width (in meters $[\mathrm{m}]$ ) to discharge (in cubic meters per second $\left[\mathrm{m}^{3} / \mathrm{s}\right]$ ) for the upstream treated main stem (A), downstream treated main stem (B), side channel (C), and Barkley canal (D), for four restoration alternatives and background conditions, in the Barkley Bear segment, Methow River, north-central Washington. 



Figure 6. Graphical functions used in the Aquatic Trophic Productivity model that relate average channel depth (in meters [m]) to discharge (in cubic meters per second $\left[\mathrm{m}^{3} / \mathrm{s}\right]$ ) for the upstream treated main stem (A), downstream treated main stem (B), side channel (C), and Barkley canal (D), for four restoration alternatives and background conditions, in the Barkley Bear segment, Methow River, north-central Washington. 



Figure 7. Graphical functions used in the Aquatic Trophic Productivity model that relate the habitat suitability index ( $\mathrm{HSI}$, in percent [\%]) to discharge (in cubic meters per second [ $\left.\mathrm{m}^{3} / \mathrm{s}\right]$ ) for the upstream treated main stem (A), downstream treated main stem (B), side channel (C), and Barkley canal (D), for four restoration alternatives and background conditions, in the Barkley Bear segment, Methow River, north-central Washington. 

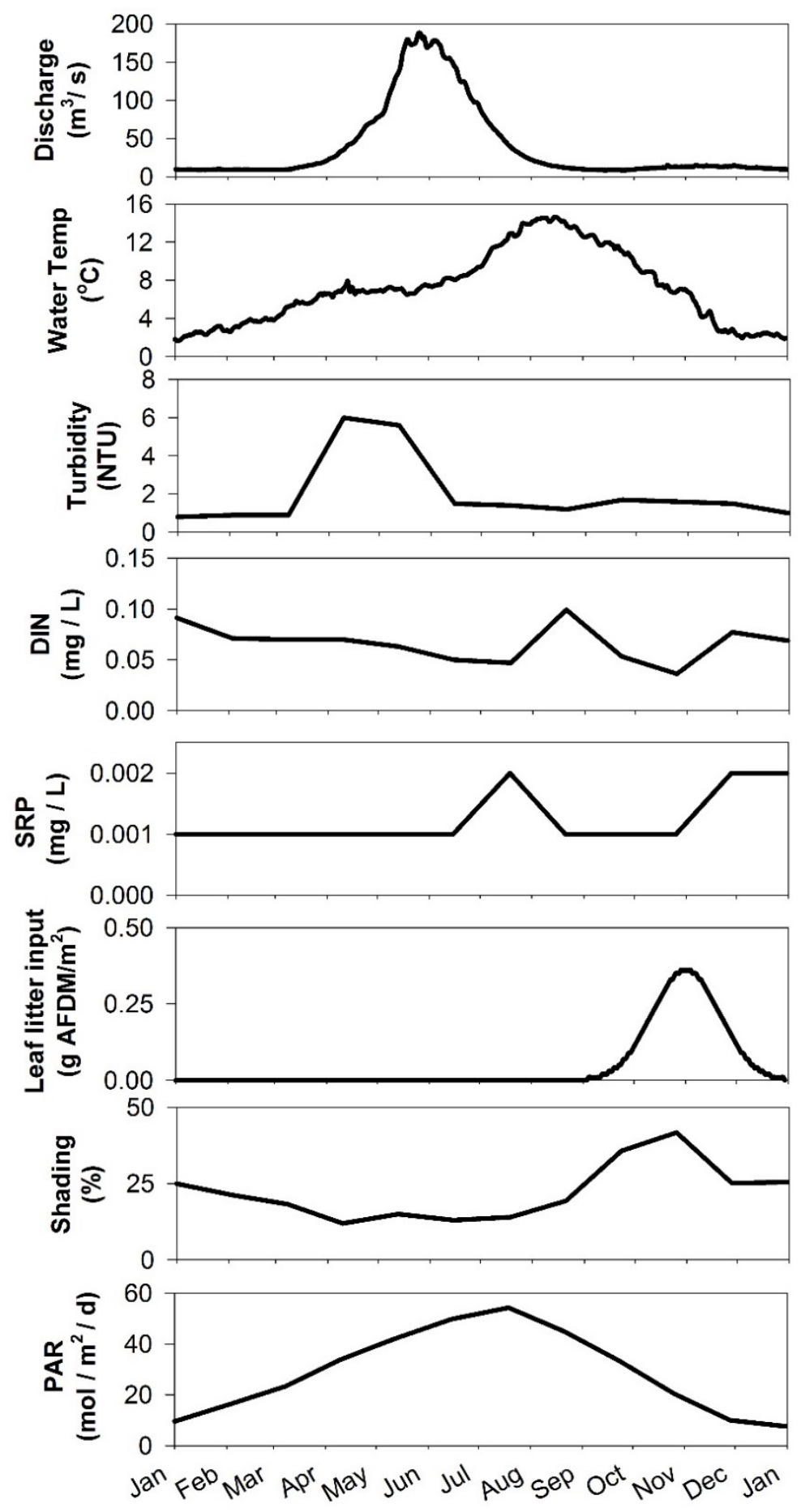

Month

Figure 8. Graphs showing temporally dynamic environmental inputs used to parameterize the Aquatic Trophic Productivity model to the Barkley Bear restoration segment of the Methow River, north-central Washington. DIN, dissolved inorganic nitrogen; Leaf litter input, lateral input of leaf litter from riparian vegetation; NTU, Nephelometric Turbidity Unit; PAR, photosynthetically active radiation; SRP, soluble reactive phosphorus; ${ }^{\circ} \mathrm{C}$, degrees Celsius; g AFDM $/ \mathrm{m}^{2}$, grams ash-free dry mass per square meter; $\mathrm{m}$, meter; $\mathrm{m}^{3} / \mathrm{s}$, cubic meter per second; mg/L, milligram per liter; [(mol/m²)/d], mole per square meter per day; \%, percent. 


\section{Sensitivity Analysis}

We conducted a 5000-simulation sensitivity analysis focused on uncertainty surrounding a subset of 30 model input parameters that were most influential in determining the biomass of fish, aquatic invertebrate, periphyton, and terrestrial detritus stocks based on previous analyses (Benjamin and Bellmore, 2016; Bellmore and others, 2017). We used a Latin Hypercube Sampling design (McKay and others, 1979), which allows for the entire range of each parameter to be evaluated.

The design team questioned how changes in discharge and temperature may the affect the carrying capacity of juvenile Chinook salmon and steelhead. Therefore, we conducted additional sensitivity analyses to address these questions. For annual fluctuations in discharge, we used hydrographs from several years that represent high (2011 and 2013), low (2012 and 2015), and average flows obtained from the National Water Information System (https://waterdata.usgs.gov/nwis/rt; USGS gage 12448500 [Methow River at Winthrop, Washington]; fig. 9A). Water temperature recorded the same year near the reach also was available (fig. 9B). We included a climate change projection scenario for year 2040 based on downscaled global circulation models for discharge (Voss and Mastin, 2012) and temperature (Caldwell and others, 2013). The design team identified the additional hydrologic and thermal regimes used in model simulations. 

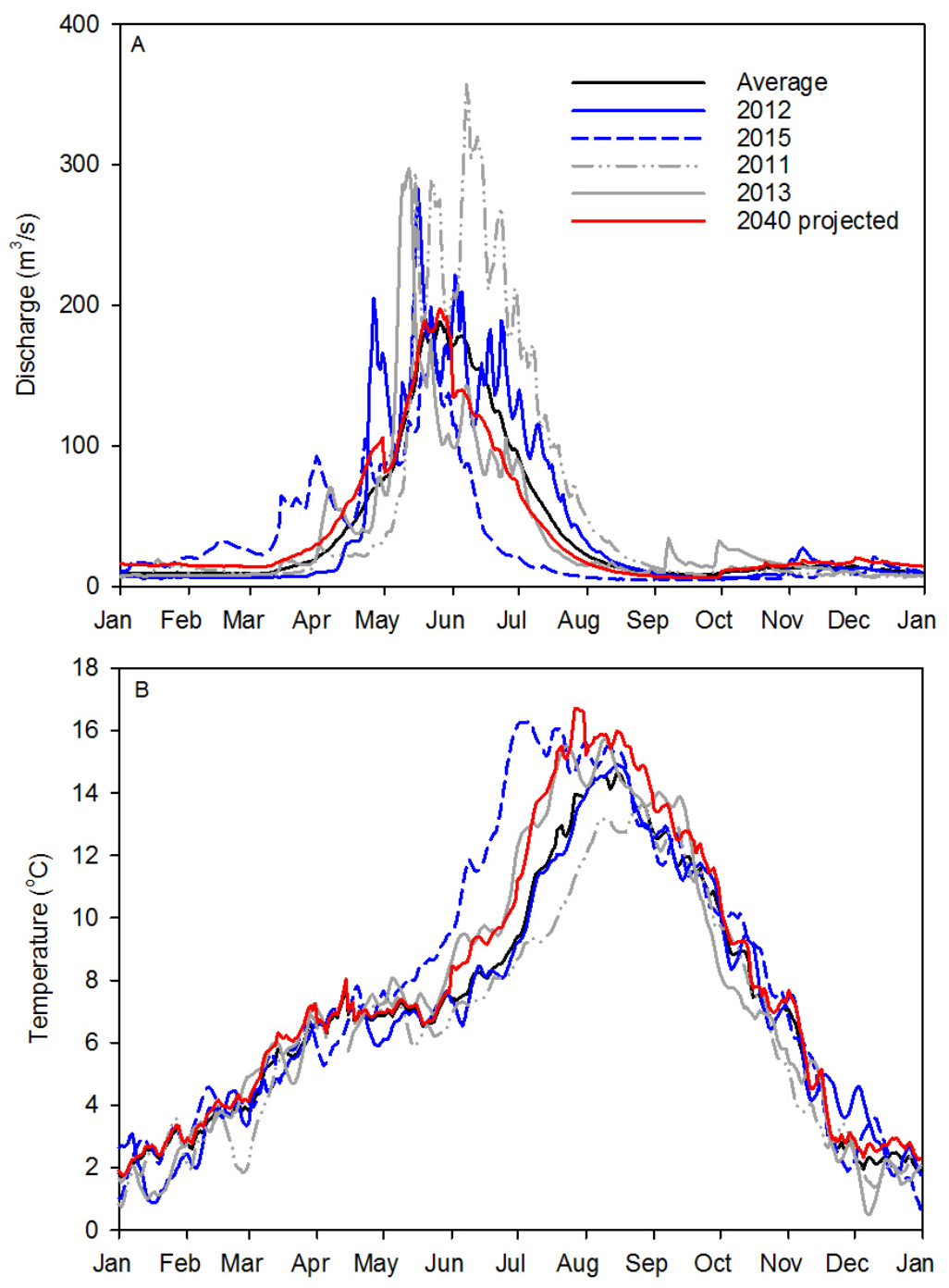

Figure 9. Graphs showing (A) annual discharge (in cubic meters per second $\left[\mathrm{m}^{3} / \mathrm{s}\right]$ as derived from U.S. Geological Survey streamgage 12448500, Methow River at Winthrop, Washington) and (B) temperature (in degrees Celsius $\left.\left[{ }^{\circ} \mathrm{C}\right]\right)$ used in model simulations, Methow River, north-central Washington. Blue lines show low water years (2012 and 2015), gray lines show high water years (2011 and 2013), red line shows climate change projection for 2040, and black line is an average across 100 years (1912-2012) for discharge and 5 years (20082012) for temperature. Black line is identical to that in figure 7. 


\section{Results and Discussion}

In the Barkley Bear segment, the ATP model showed that restoration design alternatives 3 and 4 had the greatest effect on fish carrying capacity. Both these alternatives resulted in a greater than 200-percent increase in the capacity of the Barkley Bear segment to support fish biomass (fig. 10). Alternatives 1 and 2, however, had minimal effect on the fish carrying capacity. Differences in modeled fish response across the four restoration alternatives primarily were influenced by changes in the carrying capacity of the canal, and secondarily, owing to changes in the side channel (fig. 11). Based on the model results, the optimal restoration design would include some aspect of reconnecting floodplain aquatic habitats through side channel enhancement and development. These results are consistent with previous ATP model simulations done in the middle Methow River section (Benjamin and Bellmore, 2016; Bellmore and others, 2017). Additionally, these model findings are supported by empirical food web research that indicates that juvenile salmonids consume a larger proportion of available invertebrate prey production in side channels relative to the main channel, owing to the limited competition with non-target fish (mainly larger resident salmonids and sculpin; Bellmore and others, 2013).

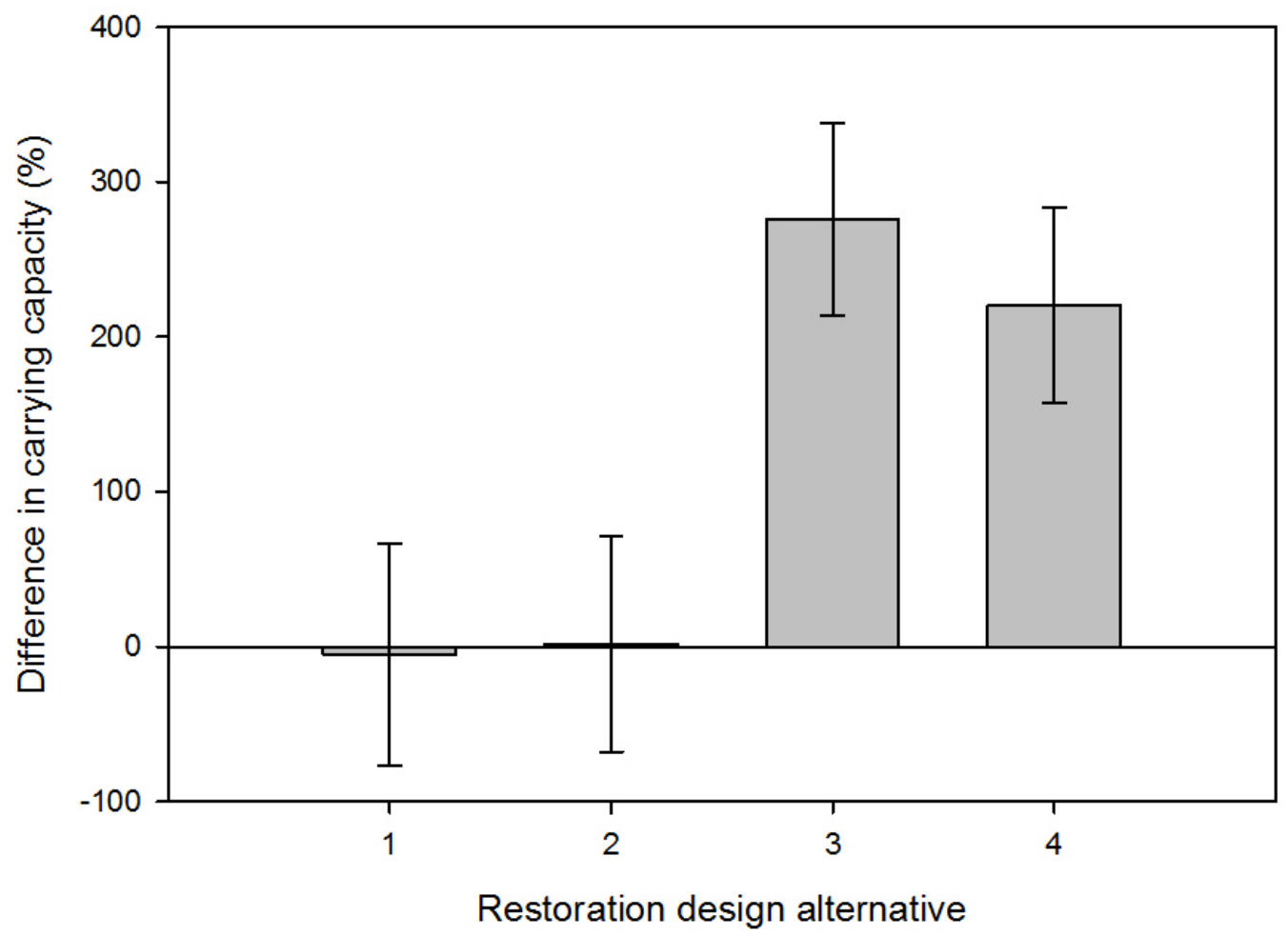

Figure 10. Graph showing percentage (\%) difference in the carrying capacity of juvenile Chinook salmon and steelhead in the Barkley Bear segment for each restoration design alternative based on Aquatic Trophic Productivity model simulations, Methow River, north-central Washington. Error bars are 1 standard deviation from the mean. 


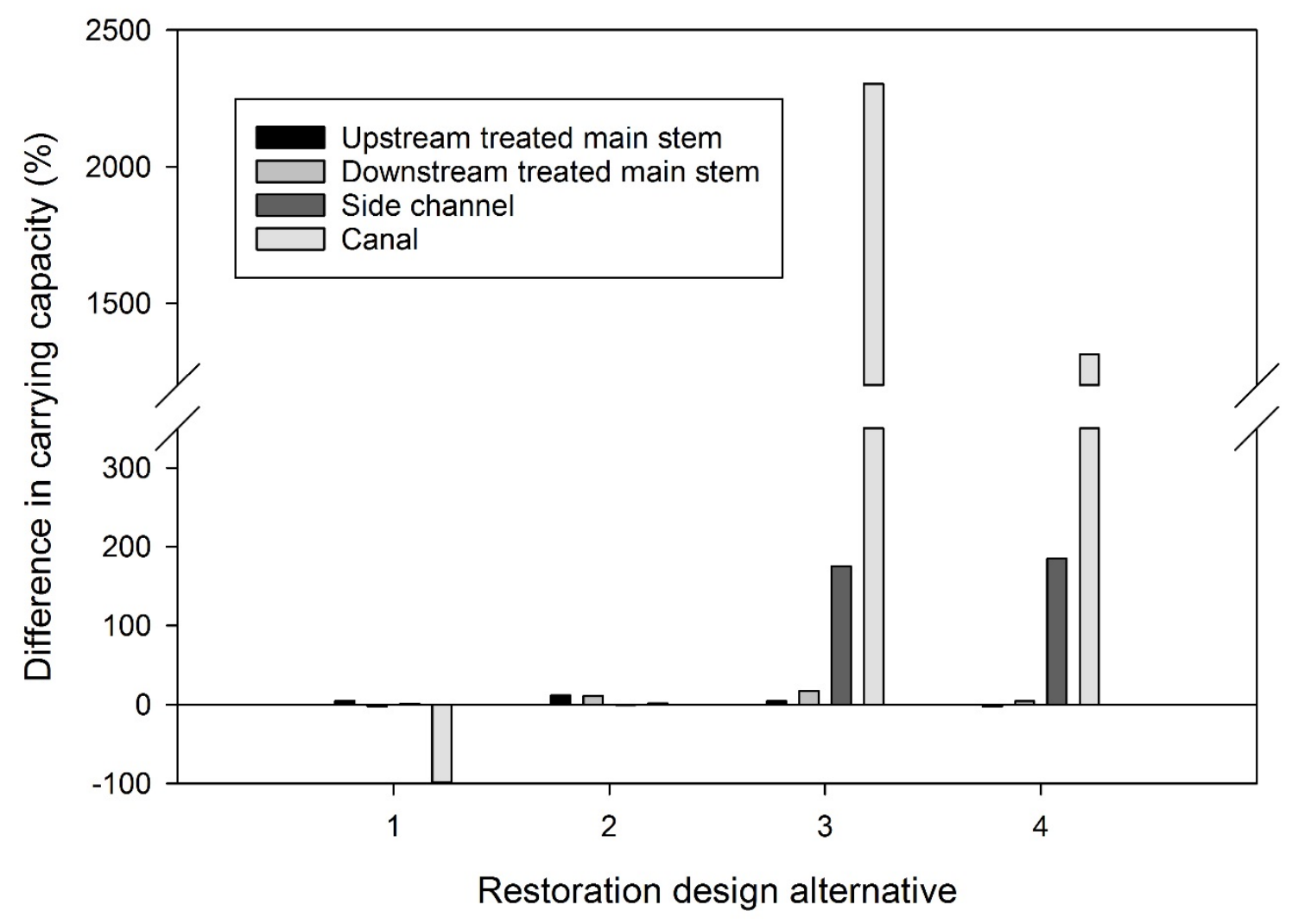

Figure 11. Graph showing percentage (\%) difference in the carrying capacity of juvenile Chinook salmon and steelhead for each river reach (see fig. 1 for locations) in the Barkley Bear segment under alternative restoration designs based on Aquatic Trophic Productivity model simulations, Methow River, north-central Washington.

Restoration design alternatives 3 and 4 were robust to changes to the discharge and thermal regimes (fig. 12). These simulations suggest that at higher discharge and cooler temperatures, the Barkley Bear segment may be capable of sustaining a greater carrying capacity of fish owing to more flow entering the side channel and canal, which increases the amount of suitable habitat (fig. 7). Under climate projections for 2040 (Voss and Mastin, 2012; Caldwell and others, 2013), the restoration design alternatives 3 and 4 increased the carrying capacity by an order of magnitude relative to alternatives 1 and 2. Caution should be used, however, when interpreting these modeled results, because future changes in discharge and temperature may alter the behavior and physiology of organisms, as well as the structure of freshwater community and associated food web (Benjamin and others, 2012; Woodward and others, 2012). Additionally, microhabitats such as groundwater, which can provide spatial and temporal refuge from extreme conditions, are not considered in the ATP model. 


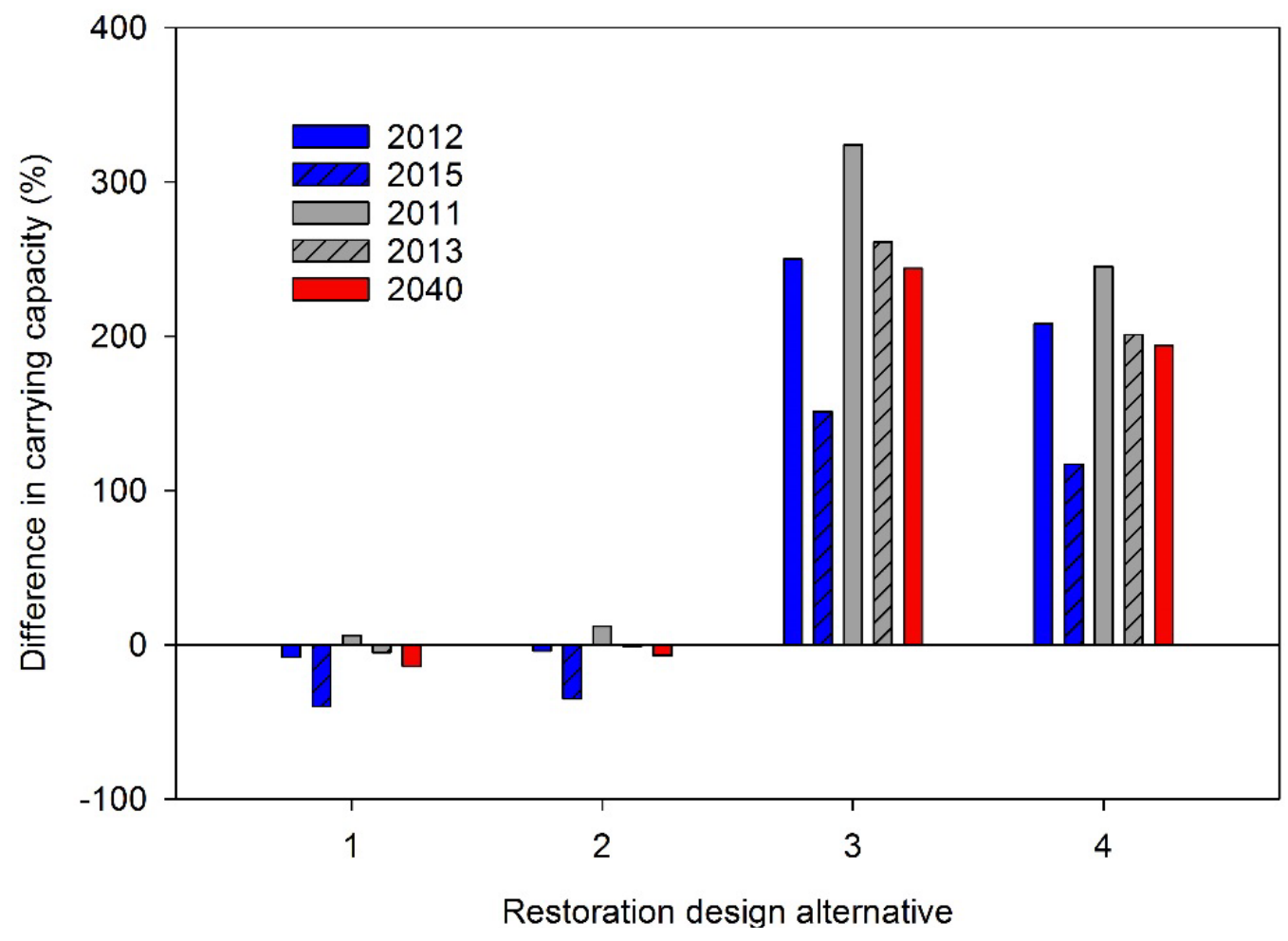

Figure 12. Graph showing percentage (\%) difference in the carrying capacity of juvenile Chinook salmon and steelhead in reach of the Barkley Bear segment for each restoration design alternative under different flow and temperature regimes, Methow River, north-central Washington. Blue bars show low water years (2012 and 2015), gray bars show high water years (2011 and 2013), and red bar shows the climate change projection for 2040.

The ATP model was developed as a decision support tool to inform restoration and management actions prior to implementation. Although the model is useful for examining specific restoration alternatives, it may be better suited for examining broader actions before specific designs are identified. For example, the ATP model can be used to rank actions such as floodplain reconnection, habitat improvements, nutrient mitigation, and riparian planting (see Bellmore and others, 2017). Similarly, the ATP model can be used to evaluate multiple actions across multiple segments within a watershed, an approach we are developing in the Methow River watershed. A graphical user interface page is being created where managers and researchers can enter site specific data to evaluate actions or conduct thought experiments. 
These simulations were done to help inform the initial stages of design planning for the Barkley Bear restoration segment. Although most restoration assessment tools focus on the direct effects of alterations on target fish species, the ATP model links the success of target fishes to the broader food web and associated energy flows that support their production. That said, the best restoration predictions likely would occur through the use of multiple models, with different sets of assumptions and associated strengths and weaknesses. For instance, the ATP model was not constructed to directly evaluate the effects of fine-scale habitat manipulations (for example, installations of hydraulic features) on fishes. Understanding the effects of these fine-scale restoration actions may best be done with individual-based models that can link changes in channel hydraulics to habitat use, behavior and survival of fish (Railsback and others, 2005, 2014). However, individual based models are typically limited to a single population of organisms, and generally do not consider broader ecological interactions, such as those incorporated in the ATP model. Thus, the use of multiple evaluation methods prior to implementing future restoration or management actions may yield the most accurate predictions of outcomes. Such a multifaceted approach may allow for the focus of limited resources on actions that result in desired management outcomes for targeted fish, as well as the broader ecosystem that supports these organisms.

\section{Acknowledgments}

We thank Brian Fisher, Mitch Mumma, and Emily Whitney for their thorough reviews of this report, as well as Jennifer Bountry, Joel Sholtes for assistance with hydraulic modeling data. The restoration design team provided valuable input for model simulations.

\section{References Cited}

Bellmore, J.R., Baxter, C.V., Martens, K.D., and Connolly, P.J., 2013, The floodplain food web mosaic - A study of its importance to salmon and steelhead with implications for their recovery: Ecological Applications, v. 23, p. 189-207.

Bellmore, J.R., Benjamin, J.R., Newsom, M., Bountry, J.A., and Dombroski, D., 2017, Incorporating food web dynamics into ecological restoration-A modeling approach for river ecosystems:

Ecological Applications, v. 27, p. 814-832.

Benjamin, J.R., and Bellmore, J.R., 2016, Aquatic trophic productivity model-A decision support model for river restoration planning in the Methow River, Washington: U.S. Geological Survey Open-File Report 2016-1075, 85 p., https://dx.doi.org/10.3133/ofr20161075.

Benjamin, J.R., Connolly, P.J., Romine, J.G., and Perry, R.W., 2012, Potential effects of changes in temperature and food resources on life history trajectories of juvenile Oncorhynchus mykiss:

Transactions of the American Fisheries Society, v. 142, p. 208-220.

Benjamin, J.R., Wetzel, L.A., Martens, K.D., Larsen, K., and Connolly, P.J., 2014, Spatio-temporal variability in movement, age, and growth of mountain whitefish (Prosopium williamsoni) in a river network based upon PIT tagging and otolith chemistry: Canadian Journal of Fisheries and Aquatic Sciences, v. 71, p. 131-140.

Bureau of Reclamation, 2010, Middle Methow reach assessment-Methow River, Okanogan County, Washington: Bureau of Reclamation, 200 p.

Bureau of Reclamation, 2012, Methow River numerical hydraulic modeling study_-Whitefish Island project area: Bureau of Reclamation, SRH Report 2012-14.

Bureau of Reclamation, 2016, Barkley Bear restoration strategy and basis of design report: Bureau of Reclamation, $76 \mathrm{p}$. 
Caldwell, R.J., Gangopadhyay, S., Bountry, J., Lai, Y., and Elsner, M.M., 2013, Statistical modeling of daily and subdaily stream temperatures-Application to the Methow River Basin, Washington:

Water Resources Research, v. 49, p. 4,346-4,361.

Dombroski, D., Greimann, B.P., and Gordon, E., 2012, Hydraulic studies for fish habitat analysis: Bureau of Reclamation report submitted to San Joaquin River Restoration Project, Technical Report No. SRH-2012-15.

Ely, D.M., 2003, Precipitation-runoff simulations of current and natural streamflow conditions in the Methow River Basin, Washington: U.S. Geological Survey Water-Resources Investigations Report 03-4246, 35 p.

Fresh, K.L., 1997, The role of competition and predation in the decline of Pacific salmon and steelhead, in Stouder, D.J., Bisson, P.A., and Naiman, R.J., eds., Pacific salmon and their ecosystems: New York, Springer, p. 245-275.

Gregory, R., Failing, L., Harstone, M., Long, G., McDaniels, T., and Ohlson, D., 2012, Structured decision making - A practical guide to environmental management choices: West Sussex, United Kingdom, Wiley-Blackwell, 299 p.

Harris, G.P., and Heathwaite, A.L., 2011, Why is achieving good ecological outcomes in rivers so difficult?: Freshwater Biology, v. 57, p. 91-107.

Independent Scientific Advisory Board, 2013, Review of the 2009 Columbia River Basin fish and wildlife program: Portland, Oregon, Independent Scientific Advisory Board for the Northwest Power and Conservation Council, Columbia River Basin Indian Tribes, and National Marine Fisheries Service, $76 \mathrm{p}$.

Jenkins, J.C., Chojnacky, D.C., Heath, L.S., and Birdsey, R.A., 2004, Comprehensive database of diameter-based biomass regressions for North American tree species: Newtown Square, Pennsylvania: U.S. Forest Service, Northeastern Research Station, General Technical Report NE319.

Kiffney, P., Buhle, E., Naman, S., Pess, G., and Klett, R., 2014, Linking resource availability and habitat structure to stream organisms-An experimental and observational assessment: Ecosphere, v. 5, p. 1-27.

Lai, Y.G., 2010, Two-dimensional depth-averaged flow modeling with an unstructured hybrid mesh: Journal of Hydraulic Engineering, v. 136, p. 12-23.

Martens, K.D., and Connolly, P.J., 2014, Juvenile anadromous salmonid production in Upper Columbia River side channels with different levels of hydrological connection: Transactions of the American Fisheries Society, v. 143, p. 757-767.

McKay, M., Beckman, R., and Conover, W., 1979, A comparison of three methods for setting values of input variables in the analysis of output from a computer code: Technometrics, v. 21, p. 55-61.

Naiman, R.J., Alldredge, J.R., Beauchamp, D.A., Bisson, P.A., Congleton, J., Henny, C.J., Huntly, N., Lamberson, R., Levings, C., Merrill, E.N., Pearcy, W.G., Rieman, B.E., Ruggerone, G.T., Scarnecchia, D., Smouse, P.E., and Wood, C.C., 2012, Developing a broader scientific foundation for river restoration - Columbia River food webs: Proceedings of the National Academy of Sciences of the United States of America, v. 109, p. 21,201-21,207.

Nehlsen, W., Williams, J.E., and Lichatowich, J.A., 1991, Pacific salmon at the crossroads-Stocks at risk from California, Oregon, Idaho, and Washington: Fisheries, v. 16, p. 4-21.

Palmer, M.A., Bernhardt, E.S., Allan, J.D., Lake, P.S., Alexander, G., Brooks, S., Carr, J., Clayton, S., Dahm, C., Follstad-Shah, J., Galat, D., Gloss, S., Goodwin, P., Hart, D., Hassett, B., Jenkinson, R., Katz, S., Kondolf, G.M., Lave, R., Meyer, J.L., O’Donnell, T.K., Pagano, L., and Sudduth, E., 2005, Standards for ecologically successful river restoration: Journal of Applied Ecology, v. 42, p. 208 217.

Power, M.E., and Dietrich, W.E., 2002, Food webs in river networks: Ecological Research, v. 17, p. $451-471$. 
Railsback, S.F., Harvey, B.C., Jackson, S.K., and Lamberson, R.H., 2005, InStream-The individualbased stream trout research and environmental assessment model: U.S. Forest Service Pacific

Southwest Research Station, Albany, California, General Technical Report PSW-GTR-218, 254 p.

Railsback, S.F., Harvey, B.C., and White, J.L., 2014, Facultative anadromy in salmonids_-Linking habitat, individual life history decisions, and population-level consequences: Canadian Journal of Fisheries and Aquatic Sciences, v. 71, p. 1-9.

Raleigh, R.F., Miller, W.J., and Nelson, P.C., 1986, Habitat suitability index models and instream flow suitability curves - Chinook salmon: U.S. Fish and Wildlife Service Biological Report 82 (10.122), $64 \mathrm{p}$.

Richardson, J.S., 1993, Limits to productivity in streams - Evidence from studies of macroinvertebrates: Canadian Special Publication of Fisheries and Aquatic Sciences v. 118, p. 9-15. Roni, P., and Beechie, T., 2013, Stream and watershed restoration-A guide to restoring riverine processes and habitats: West Sussex, United Kingdom, Wiley.

Voss, F.D., and Mastin, M.C., 2012, Simulation of streamflows and basin-wide hydrologic variables over several climate-change scenarios, Methow River Basin, Washington: U.S. Geological Survey Scientific Investigations Report 2012-5031, 18 p. plus climate change web tools available at https://wa.water.usgs.gov/projects/methowcc/welcome.aspx.

Wipfli, M.S., and Baxter, C.V., 2010, Linking ecosystems, food webs, and fish production-Subsidies in salmonid watersheds: Fisheries, v. 35, p. 373-387.

Woodward, G., Jacob, U., and O'Gorman, E.J., 2012, Global change in multispecies systems_-Part 2, v. 47 of Advances in ecological research book series: Burlington, Massachusetts, Academic Press, p. $2-510$.

Yard, M.D., Coggins, L.G., Baxter, C.V., Bennett, G.E., and Korman, J., 2011, Trout piscivory in the Colorado River, Grand Canyon-Effects of turbidity, temperature, and fish prey availability: Transactions of the American Fisheries Society, v. 140, p. 471-486. 
Publishing support provided by the U.S. Geological Survey Science Publishing Network, Tacoma Publishing Service Center

For more information concerning the research in this report, contact the Director, Forest and Rangeland Ecosystem Science Center U.S. Geological Survey

777 NW 9th St., Suite 400

Corvallis, Oregon 97330

https://fresc.usgs.gov/ 


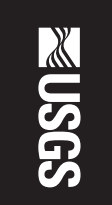

品

ㄱ. ․․‥

亏ํำ

울

올.

今

$\sum_{8}$

금

邑.

꿍

Ф

君

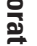

